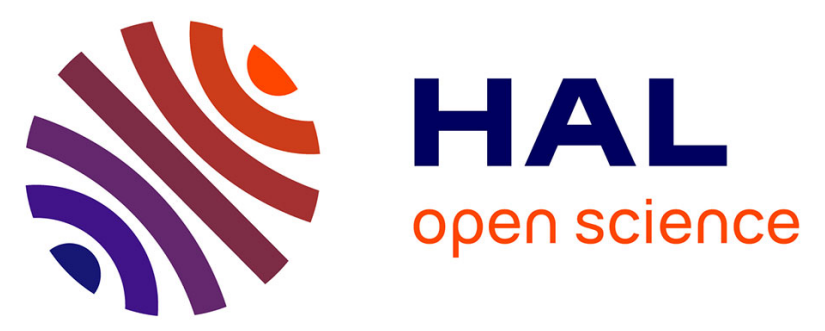

\title{
A comparative analysis of foliar chemical composition and leaf construction costs of beech (Fagus sylvatica L.), sycamore maple (Acer pseudoplatanus L.) and ash (Fraxinus excelsior L.) saplings along a light gradient
}

Any Mary Petritan, Burghard von Lüpke, Ion Catalin Petritan

\section{To cite this version:}

Any Mary Petritan, Burghard von Lüpke, Ion Catalin Petritan. A comparative analysis of foliar chemical composition and leaf construction costs of beech (Fagus sylvatica L.), sycamore maple (Acer pseudoplatanus L.) and ash (Fraxinus excelsior L.) saplings along a light gradient. Annals of Forest Science, 2010, 67 (6), 10.1051/forest/2010023 . hal-00883638

\section{HAL Id: hal-00883638 \\ https://hal.science/hal-00883638}

Submitted on 1 Jan 2010

HAL is a multi-disciplinary open access archive for the deposit and dissemination of scientific research documents, whether they are published or not. The documents may come from teaching and research institutions in France or abroad, or from public or private research centers.
L'archive ouverte pluridisciplinaire HAL, est destinée au dépôt et à la diffusion de documents scientifiques de niveau recherche, publiés ou non, émanant des établissements d'enseignement et de recherche français ou étrangers, des laboratoires publics ou privés. 


\title{
A comparative analysis of foliar chemical composition and leaf construction costs of beech (Fagus sylvatica L.), sycamore maple (Acer pseudoplatanus L.) and ash (Fraxinus excelsior L.) saplings along a light gradient
}

\author{
Any Mary PETRITAN ${ }^{1,2 *}$, Burghard von LÜPKE ${ }^{1}$, Ion Catalin PETRITAN ${ }^{1}$ \\ ${ }^{1}$ Department of Silviculture and Forest Ecology of the Temperate Zones, Georg-August University Göttingen, Büsgenweg 1, \\ 37077 Göttingen, Germany \\ ${ }^{2}$ Department of Silviculture and Forest Ecology, Institute of Forest Research and Management, Closca 13, 500040 Brasov, Romania
}

(Received 19 August 2009; accepted 1 December 2009)

Keywords:

leaf construction cost /

foliar chemical composition /

shade tolerance /

mixed species broad leaf stand /

irradiance

\begin{abstract}
- Construction cost (g glucose $\mathrm{g}^{-1}$ ), chemical composition and morphology of leaves of beech (Fagus sylvatica L.) and two co-occurring valuable broadleaved species (sycamore maple-Acer pseudoplatanus L. - and ash - Fraxinus excelsior L.) were investigated along a horizontal light gradient (3-60\% of above canopy radiation) and from top to bottom within the crowns in a fairly even-aged mixedspecies thicket established by natural regeneration beneath a patchy shelterwood canopy.

- Construction cost and carbon concentration increased with irradiance in ash and sycamore maple and were independent of irradiance in beech. Leaf traits expressed on an area basis, like construction cost, nitrogen content and leaf mass (LMA) increased significantly with irradiance in all three species and decreased from top to bottom within crowns.

- The shade tolerant beech invested more glucose to produce a unit foliar biomass, but less to build a unit foliar area due to lower LMA. Thereby beech was able to display a greater total leaf area, what at least in parts counterbalanced the lower values of $N_{\mathrm{a}}$ as compared to ash and sycamore maple.
\end{abstract}

\section{INTRODUCTION}

Among the various growth factors, light plays an outstandig role in forests, at least on mesic sites in temperate regions (Kimmins, 1997), and it can easily be manipulated by silvicultural means (Röhrig et al., 2006). One of the most responsive traits to light change is leaf morphology. Particularly the measure "leaf mass per unit leaf area" (LMA, $\mathrm{g} \mathrm{m}^{-2}$ ) or its inverse "specific leaf area" (SLA, $\mathrm{m}^{2} \mathrm{~g}^{-1}$ ) is know as an appropiate acclimation to enhance the carbon assimilation potential of plants: higher LMA enables increased carbon acquisition in high light, while lower LMA improves light harvesting in low light (Niinemets and Tenhunen, 1997). LMA increases with increasing irradiance, a reaction which most plants - if not all - show in such a pronounced manner that LMA even has been proposed as a suitable species-specific estimator of long term light climate (Niinemets, 1997). The modification in leaf morphology is further accompanied by changes in foliar chemistry (Niinemets, 1999). A lower LMA in low light is coupled with lower nitrogen content per unit leaf area $\left(N_{\mathrm{a}}\right.$,

*Corresponding author: apetrit@gwdg.de $\mathrm{g} \mathrm{N} \mathrm{m}^{-2}$ ) and lower photosynthetic capacity per unit leaf area (Frak et al., 2001; Le Roux et al., 2001). $N_{\text {a }}$ generally is positively related to irradiance and by this also to crown position. It increases within the crown from bottom to top (Kull and Niinemets, 1993; Niinemets, 1995). Ellsworth and Reich (1993) observed an increase of $N_{\mathrm{a}}$ and photosynthetic capacity within the canopy from bottom to top in an 18-m tall Acer saccharum stand and explained this pattern as a direct consequence of the vertical variation of LMA since leaf $\mathrm{N}$ concentration per unit mass was independent of canopy position. The authors consider the observed LMA distribution pattern within the canopy as responsible for an up to $45 \%$ higher photosynthetic yield as compared with a homogeneous distribution.

Irradiance may also influence the proportion of carbon invested in structural components in leaves. Niinemets and Kull (1998) found that lignin concentrations increased at the expense of cellulose and hemicellulose with increasing irradiance. Inasmuch as lignin contains more carbon than cell wall polysaccharides, and as carbon concentration and the energetic costs of foliage construction (CC, g glucose $\mathrm{g}^{-1}$, Vertregt and Penning de Vries, 1987) are directly linked, Niinemets (1999) assumed that leaf construction requires more energy 
with increasing irradiance. But reports on the response of CC to varying irradiance are not consistent. Whereas some authors found CC to be lower at high light (Sims and Pearcy, 1994), others show higher values at high light (Barthod and Epron, 2005; Niinemets, 1999; Poorter et al., 2006).

All these morphological and physiological leaf acclimation to varying irradiance are thought to contribute to shade tolerance of tree species. In an exhaustive review Valladares and Niinemets (2008) stated that shade tolerance is a "complex, multifaceted property of plants that is achieved by different suites of traits in different species". They analysed key points and supporting evidence of the two major hypotheses regarding the suites of traits responsible for species' shade tolerance: (i) efficiency of carbon gain in low light (Givnish, 1988) and (ii) stress tolerance in understorey conditions (Kitajima, 1994). An extension of the first hyphothesis on carbon gain is a assumed trade-off between a high survival rate under low light and high growth in high-light (Kobe et al., 1995). In a previous study (Petriţan et al., 2007) carried out on saplings in mixed-stands of sycamore maple (Acer pseudoplatanus), ash (Fraxinus excelsior) and beech (Fagus sylvatica) we took this hypothesis as a basis and found that beech showed the highest survivorship in shade and the lowest growth rate in high-light and hence could be ranked as shade-tolerant. For sycamore maple and ash the same criteria led to a ranking as mid-tolerant species. Another companion study, covering a more extended light gradient (3-60\% of above canopy radiation), confirmed these shade-tolerance ranks (Petrițan et al., 2009). Beech had a greater specific leaf area (SLA), greater total leaf area per unit tree height, and showed the greatest plasticity in traits that improve leaf display in shade, like plagiotropy or a sturdier leaf support system. Ash and sycamore maple showed a marked and constant increase in growth rates with increasing irradiance and an inability to strongly reduce their growth rates in deep shade. They displayed most of their leaf area at the top of the crown, while beech displayed its leaves along the entire tree height. These different species-specific patterns caused further investigations into morphological and biochemical foliage characteristics, both along the horizontal (below a patchy canopy of a shelterwood) and the vertical light gradient (within the crowns). The results build the topic of the present report.

Generally, shade tolerant species had lower LMA (as mean value of plants growing in their natural environment), $N_{\mathrm{a}}$ (mean value as before) and photosynthetic capacity per area (Hallik et al., 2009; Valladares and Niinemets, 2008; Whright et al., 2004). To what extent these attributes of shade tolerance influence leaf construction costs has rarely been studied. Niinemets and Kull (1998) and Niinemets (1999) published the assumption that leaves of shade-tolerant species should contain more carbon and hence be more expensive to construct than leaves of shade-intolerant species.

Due to the scarcity of data about leaf construction cost and leaf chemical composition in relation to light requirements of woody species, we considered it useful to investigate whether the above described interspecific differences in shade tolerance of the three species in our companion studies (Petritan et al., 2007 ; 2009) are connected with species-specific leaf construc- tion costs and leaf chemical modifications. For this test we phrased the following hypotheses:

(1) along a natural horizontal light gradient we espect that leaves of saplings growing under high light have higher construction costs (CC), higher carbon content and higher nitrogen content per unit area $\left(N_{\mathrm{a}}\right)$ than leaves of saplings growing in shade;

(2) the variation of foliar nitrogen content and leaf construction cost within a crown from base to top is comparable with that of the horizontal light gradient;

(3) under common light conditions, beech as our most shade tolerant species has higher leaf construction cost (CC), higher leaf carbon content and lower leaf nitrogen content $\left(N_{\mathrm{a}}\right)$ than the less shade tolerant sycamore maple and ash.

\section{MATERIALS AND METHODS}

\subsection{Study site}

The study was carried out in a mixed deciduous stand with an overstory of 120 year old beech (Fagus sylvatica), hornbeam (Carpinus betulus), ash (Fraxinus excelsior), sycamore maple (Acer pseudoplatanus), Norway maple (Acer platanoides), and sessile oak (Quercus petraea), located in the community forest Wibbecke, near Göttingen (Lower Saxony, Germany, $10^{\circ} 02^{\prime} 11^{\prime \prime}$ E, $51^{\circ} 34^{\prime} 46^{\prime \prime} \mathrm{N}$ ). The site is characterized by shallow limestone plateau with rendzina soil or partly haplic luvisol, rich in nutrient supply, but rather poor in water supply during dry periods in summer. Altitude above sea level ranges from 151 to $200 \mathrm{~m}$, mean annual rainfall is $780 \mathrm{~mm}(370 \mathrm{~mm}$ in the growing season), and average annual temperature is $7,8^{\circ} \mathrm{C}$. $20-30$ y ago natural regeneration started. Within the last 10 y no harvesting or silvicultural interventions have been carried out. Thus, we can assume fairly stable canopy conditions in the overstory during this period. The canopy closure is patchy, ranging from fully closed parts to large gaps. Thus, it provides a broad gradient of light conditions in the understory. The regeneration layer is now in the thicket stage with a top height of 6-8 $\mathrm{m}$.

\subsection{Sapling measurements}

In August 2006, 129 randomly selected saplings (43 sycamore maple, 41 beech, and 45 ash trees) were sampled, free of apparent damage, growing in a large range of light environments. Mean age, estimated by counting growth rings at $10 \mathrm{~cm}$ above ground, and total height of saplings were not significantly different between the species. The beeches were $2.85 \pm 0.22 \mathrm{~m}$ (mean \pm SE) tall and $14.4 \pm 0.8 \mathrm{y}$ old, the ashes $3.15 \pm 0.22 \mathrm{~m}$ tall and $14.4 \pm 0.4 \mathrm{y}$ old; the sycamore maples had approximately the same mean height $(2.83 \pm 0.21 \mathrm{~m})$, but were slightly younger $(12.7 \pm 0.5 \mathrm{y})$. The sampled saplings of each species were evenly distributed along the same light gradient, ranging from 2.3 to $59.6 \%$ ISF (indirect site factor, expressed as diffuse light in \% of above canopy diffuse light), and a mean value of 24.1-26.3\% ISF (differences between species were not significant; for more details see Petriţan et al., 2009).

Irradiance was quantified by taking a hemispherical photo just above the uppermost leaves of every sampled sapling in mid-summer with a Nikon digital camera with fisheye lens and a self-levelling 
mount. Photos were processed with the Winscanopy software (Regents Instruments Inc., Sainte-Foy, Quebec, 2003). As a measure of light intensity, we used the indirect site factor (ISF) in percent of above canopy light, which is based on difuse radiation. Under our conditions, this measure proved as a reliable proxy of total growing season's photosynthetically active radiation since ISF and total site factor (including diffuse and direct radiation) were strongly correlated with $R^{2}=0.94$ and $p<0.001$.

Each sapling was divided into five horizontal layers of equal height $(=1 / 5$ of total height). A random sample of 50 leaves (with petioles) per layer (or all if there were less than 50) was used for area measurements with LI-3100 Area Meter (LI-COR, Inc., 1987) and subsequent drying (at $70{ }^{\circ} \mathrm{C}$ for three days) and weighing. For all other leaves (also with petioles), only dry weights were determined. Using the ratio of leaf weight to leaf area of the subsamples, we calculated for each layer the area of the rest of the leaves. The sum of leaf areas and leaf masses of the individual layers made up the total leaf area and leaf mass of the sapling. The ratio between leaf mass and leaf area (LMA, in $\mathrm{g} \mathrm{m}^{-2}$ leaf area) was determined on layer and total plant level.

For the random leaf sample, foliar carbon $\left(\mathrm{C}, \mathrm{g} \mathrm{g}^{-1}\right)$ and nitrogen $\left(\mathrm{N}, \mathrm{g} \mathrm{g}^{-1}\right)$ concentrations were estimated with an elemental analyzer (Model 1500 , Carbo Erba, Italy). Ash content was determinated after combustion of samples in a muffle furnace at $550{ }^{\circ} \mathrm{C}$ for $6 \mathrm{~h}$ by weighing the remaining mass afterwards, and total mineral content (TM, $\mathrm{g} \mathrm{g}^{-1}$ ) was calculated by assuming that the fraction of minerals in ash was equal to 0.67 (Vertregt and Penning de Vries, 1987).

Construction cost $\left(\mathrm{CC}, \mathrm{g}\right.$ glucose $\mathrm{g}^{-1}$ ) was calculated following the approach of Vertregt and Penning de Vries (1987), slightly modified by Barthod and Epron (2005), from carbon (C, $\mathrm{g} \mathrm{g}^{-1}$ ) and ash $\left(\mathrm{A}, \mathrm{g} \mathrm{g}^{-1}\right)$ contents, assuming that the reduction state of organic compounds is related to their carbon content:

$$
\mathrm{CC}=[-1.041+5.077 C /(1-A)](1-A) .
$$

Leaf construction cost per unit leaf area (Leaf $\mathrm{CC}_{\mathrm{A}}$, g glucose $\mathrm{m}^{-2}$ ) was the product of leaf specifc $\mathrm{CC}$ and leaf mass area (LMA).

All leaf traits $\left(\mathrm{CC}, \mathrm{CC}_{\mathrm{A}}, \mathrm{N}, \mathrm{C}, \mathrm{TM}\right.$, and LMA) were calculated separately for each of the five layers, and for the whole plant as one leaf mass-weighted mean.

When analysing the vertical distribution of various foliar traits within the crowns of the sampled saplings, we left out the lowest layer $\mathrm{S} 1$ because most of the sampled sycamore maple and ash saplings had no leaves there (see Petriţan et al., 2009).

\subsection{Data analysis}

Linear regression analysis was used to test the influence of light on foliar construction costs and foliar chemical contents of sampled saplings. To compare leaf parameters between species along a light gradient we used analysis of covariance (ANCOVA) with Scheffé's post hoc test, taking species as the main effect and light as the covariate.

Data of the co-variable were transformed to its natural logarithm when necessary to reach residue normality and variance homogeneity needed for the analyses (normality of residuals was tested with Kolmogorov-Smirnov test and homoscedasticity with Levenè test). Differences between layer values were tested using the nonparametric Wilcoxon-pair test in cases the data did not comply with the requirements of parametric test methods. Between some leaf traits
Pearson correlation coefficients $(r)$ were calculated. All statistical analyses were performed using Statistica 7.1 (StatSoft, Inc., 2005).

\section{RESULTS}

Leaf construction cost (CC) increased with increasing irradiance in ash and sycamore maple $(p<0.01)$, but was independent of light in beech (Fig. 1A). Across the whole light gradient, beech had the highest, ash the lowest (1.44 vs. $1.29 \mathrm{~g}_{\text {glucose }} \mathrm{g}^{-1}$ ) and sycamore maple an intermediate mean value (1.37), with significant differences between all three species (Tab. I). With increasing LMA, CC gained significantly in sycamore maple $(r=0.47, p<0.01)$, and remained almost constant in ash and beech $(p>0.05)$ (data not shown).

The relationship between leaf construction cost $\left(\mathrm{CC}_{\mathrm{A}}\right)$, and irradiance showed a steeper increase than with CC (Fig. 1B). A reason can be seen in the strong positive correlation between LMA and light for all species $(r>0.86, p<0.001)$. The values of $\mathrm{CC}_{\mathrm{A}}$ of the two less shade tolerant species were almost equal and significantly exceeded those of beech across the whole light gradient (Tab. I).

While leaf mass based nitrogen content $\left(N_{\mathrm{m}}\right)$ remained almost constant with increasing shade $(p>0.05$, Tab. I), leaf nitrogen per unit area $\left(N_{\mathrm{a}}\right)$ decreased significantly in all three species $(p<0.01$, Fig. 1C). In both traits, beech differed significantly from the other two species and possessed the highest value in $N_{\mathrm{m}}$ and the lowest in $N_{\mathrm{a}}$ (Tab. I). The relationship between leaf nitrogen per unit area $\left(N_{\mathrm{a}}\right)$ and leaf dry mass per unit area (LMA) was linear, positive and significant for all three species ( $r=0.98$ for beech, $r=0.85$ for sycamore maple and $r=0.93$ for ash, $p<0.001)$.

There was a positive correlation between leaf carbon concentration (C) and light in ash and sycamore maple, but not in beech $(p>0.05)$ (data not shown). This corresponded well with construction costs with beech possessing the highest value and ash the lowest. Accordingly, we found in all three species a strong and positive correlation between $\mathrm{CC}$ and $\mathrm{C}$ with $r>0.94$ and $p<0.001$.

Leaf total mineral content (TM) decreased significantly with increasing light in ash and sycamore maple $(p<0.001)$ (Fig. 1D). Ash had the highest mean value (59.1 $\mathrm{g} \mathrm{g}^{-1}$ ), sycamore maple followed (46.5) whereas beech had the lowest (31.1) (Tab. I). Leaf construction costs $(C C)$ were negatively correlated with total mineral concentration (TM), significantly for ash $(r=-0.44, p<0.05)$ and sycamore maple $(r=-0.38$, $p<0.05)$, not significantly for beech $(r=-0.15, p>0.05)$. Total mineral concentration declined with carbon concentration in all species (Fig. 2, significantly only in sycamore maple and ash with $p<0.001)$. It also decreased with increasing leaf carbon concentration in the following order: ash $<$ sycamore maple $<$ beech.

The vertical distribution of various foliar traits within the crowns of the sampled saplings mirrored on the whole the above described relationships with irradiance measured above the crowns. Only leaf construction costs (Fig. 3A) did not differ significantly between the four layers in all three species, whereas they significantly rose with increasing light above the 

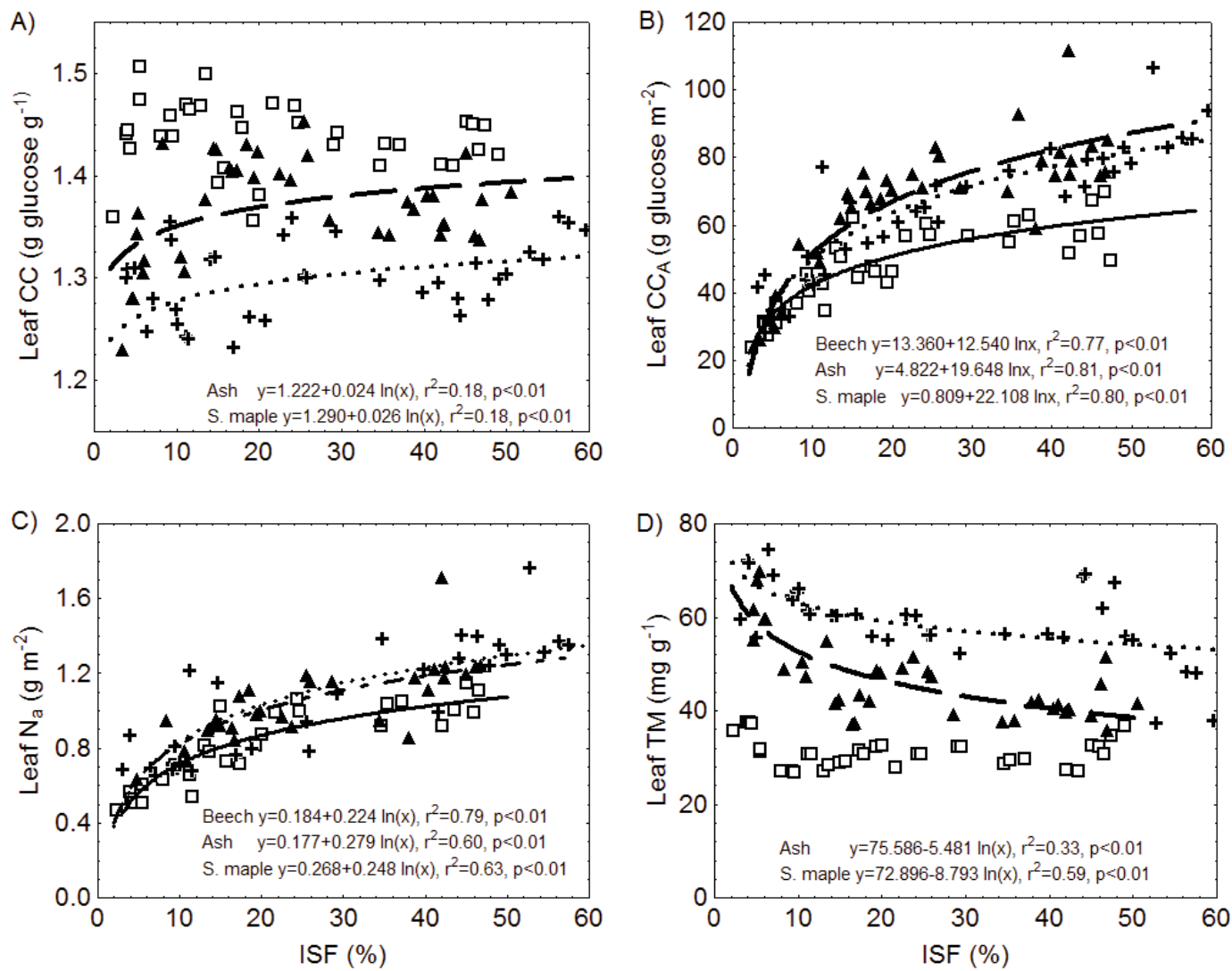

Figure 1. Logarithmic regression analyses between irradiance (ISF \%) and the following parameters: (A) leaf specific construction costs (CC), (B) area related leaf construction costs $\left(\mathrm{CC}_{\mathrm{a}}\right),(\mathrm{C})$ leaf nitrogen content per unit area $\left(N_{\mathrm{a}}\right)$, and (D) leaf total mineral content $(\mathrm{TM})$. In case of significant interrelations regression lines and equations are shown. Beech (open squares and solid lines), ash (crosses and short-dashed broken line), and sycamore maple (solid triangles and long-dashed broken line).

Table I. Species mean values across the whole light gradient for various foliar parameters and the ANCOVA results $(F$ values and significant levels for light, species and their interaction effect, coefficient of determination of the model, and values of the covariant for which means are adjusted): Construction cost (mass based $-\mathrm{CC}$; area based $-\mathrm{CC}_{\mathrm{A}}$ ); concentration of $N$ (mass based $-N_{\mathrm{m}}$; area based $-N_{\mathrm{a}}$ ), C and total mineral (TM); and ratio of mass per unit area (LMA). Mean values with the same letter denote not significant differences between species (Scheffé-test, $P>0.05$; results of analyses of covariance - one-way ANCOVA -, with the species as the main effect and light as the covariate). $F$ ratio followed by $* * *$ or $* * *$ are significantly higher than unity at $0.05,0.01$ and 0.001 respectively. The covariate variable light was log-transformed.

\begin{tabular}{|c|c|c|c|c|c|c|c|c|}
\hline \multirow{3}{*}{$\begin{array}{l}\text { Leaf parameter } \\
(\text { mean } \pm \mathrm{SE})\end{array}$} & \multicolumn{3}{|c|}{ Scheffé-test results } & Light & Species & $\begin{array}{l}\text { Light } \times \\
\text { Species }\end{array}$ & \multirow{3}{*}{$\begin{array}{c}R^{2} \\
I S F(\%)\end{array}$} & \multirow{3}{*}{$\begin{array}{l}\text { Values of the } \\
\text { covariant for } \\
\text { which means } \\
\text { are adjusted }\end{array}$} \\
\hline & & & & & & & & \\
\hline & F. sylvatica & platanus & F. excelsior & $F$ & $F$ & $F$ & & \\
\hline $\mathrm{CC}\left(\mathrm{g}_{\text {glucose }} \mathrm{g}^{-1}\right)$ & $1.44 \pm 0.01 \mathrm{a}$ & $1.37 \pm 0.01 b$ & $1.29 \pm 0.01 \mathrm{c}$ & $6.2^{*}$ & $106.8 * * *$ & $3.4^{*}$ & 0.67 & 25.1 \\
\hline $\mathrm{CC}_{\mathrm{A}}\left(\mathrm{g}\right.$ glucose $\left.\mathrm{m}^{-2}\right)$ & $48.11 \pm 2.14 \mathrm{a}$ & $65.39 \pm 3.22 b$ & $63.66 \pm 3.21 b$ & $366.1 * * *$ & $26.5^{* * *}$ & $8.7 * * *$ & 0.79 & 25.1 \\
\hline$N_{\mathrm{m}}\left(\mathrm{mg} \mathrm{g}^{-1}\right)$ & $24.1 \pm 0.2 \mathrm{a}$ & $20.7 \pm 0.4 b$ & $20.6 \pm 0.5 b$ & 9.01 & $16.3 *$ & 5.1 & 0.34 & 25.6 \\
\hline$N_{\mathrm{a}}\left(\mathrm{g} \mathrm{m}^{-2}\right)$ & $0.81 \pm 0.04 \mathrm{a}$ & $1.03 \pm 0.04 \mathrm{~b}$ & $1.04 \pm 0.05 \mathrm{~b}$ & $165.7 * * *$ & $10.2 *$ & 0.7 & 0.69 & 25.6 \\
\hline $\mathrm{C}\left(\mathrm{mg} \mathrm{g}^{-1}\right)$ & $479.2 \pm 1.3 \mathrm{a}$ & $461.7 \pm 2.1 b$ & $443.4 \pm 1.2 \mathrm{c}$ & $15.3^{*}$ & $29.8 * * *$ & $4.5^{*}$ & 0.78 & 25.2 \\
\hline $\mathrm{TM}\left(\mathrm{mg} \mathrm{g}^{-1}\right)$ & $31.1 \pm 0.5 \mathrm{a}$ & $46.5 \pm 1.4 \mathrm{~b}$ & $59.1 \pm 1.3 \mathrm{c}$ & $61.6^{* *}$ & $47.8 * *$ & $11.1^{*}$ & 0.81 & 25.1 \\
\hline $\operatorname{LMA}\left(\mathrm{g} \mathrm{m}^{-2}\right)$ & $33.84 \pm 1.35 \mathrm{a}$ & $47.37 \pm 2.27 \mathrm{~b}$ & $48.61 \pm 2.09 \mathrm{~b}$ & $450.4 * * *$ & $2.3^{*}$ & $14.7 *$ & 0.83 & 23.8 \\
\hline
\end{tabular}




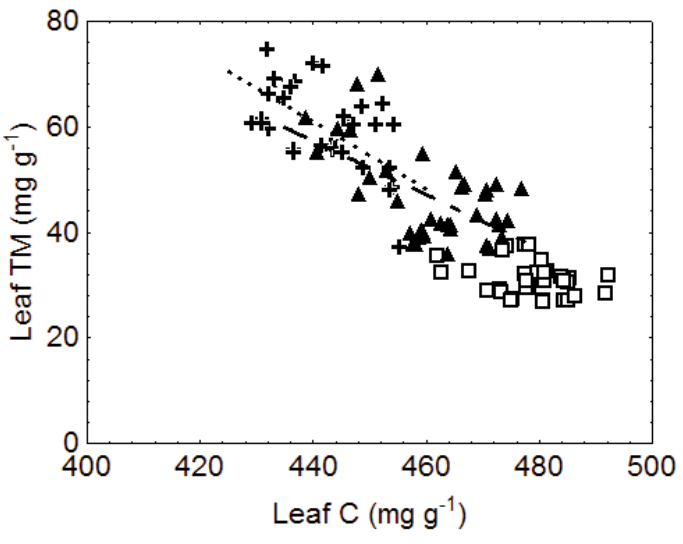

Figure 2. Total mineral concentration in relation to foliar carbon concentration of beech (open squares), ash (crosses), and sycamore maple (solid triangles). In case of significant interrelations regression lines are shown: ash (short-dashed broken line), and sycamore maple (long-dashed broken line).

crowns in sycamore maple and ash. $N_{\mathrm{m}}$ showed neither clear relationship with height within the crowns (Fig. 3C) nor with irradiance above the crowns (Tab. I).

Both area based parameters, $\mathrm{CC}_{\mathrm{A}}$ and $N_{\mathrm{a}}$, displayed a consistent behaviour in relation to increasing height within the crown (Figs. 3B and 3D) as well as with increasing irradiance above the crowns (Figs. 1B and 1C). In all three species, mean $\mathrm{CC}_{\mathrm{A}}$ and mean $N_{\mathrm{a}}$ of the lowest layer $\mathrm{S} 2$ differed significantly from the top most layer S5.

\section{DISCUSSION}

Generally, leaf construction cost values reported in the literature vary between 1.2 and $1.8 \mathrm{~g}_{\text {glucose }} \mathrm{g}^{-1}$ (Poorter and Villar, 1997; Poorter et al., 2006). For European broadleaved deciduous species, Niinemets (1999) found a variability of construction costs of ca. $25 \%$ with a range of $1.23-1.53 \mathrm{~g}$ glucose $\mathrm{g}^{-1}$. Our leaf construction costs for species means reached from 1.23 to $1.51 \mathrm{~g}$ glucose $\mathrm{g}^{-1}$ with a variability of $22 \%$ and cover well the interval reported by Niinemets.

The relationship between leaf construction cost (CC) and irradiance does not show a uniform pattern, neither in our results, nor in results reported by other authors. In our study the more light demanding species sycamore maple and ash had increasing CC with increasing light whereas $\mathrm{CC}$ in shade tolerant beech was independent of light (Fig. 1A). Other studies found (i) the same pattern as in our sycamore maple and ash: CC increased with increasing light in Fraxinus excelsior (Barthod and Epron, 2005; Niinemets, 1999), Corylus avellana, Tilia cordata (Niinemets, 1999), Acer platanoides (Barthod and Epron, 2005), herbs, European and Amazonian tree species (Poorter et al., 2006); (ii) the same pattern as in our beech: CC was light-independent in Populus tremula, Fagus sylvatica (Niinemets, 1999); (iii) and a different pattern not met in our study: CC decreased in the herb Alocasia macrorrhiza (Sims and Pearcy, 1994).
In all cases, however, leaf construction cost changes with light were rather small. Poorter et al. (2006) compiled literature data and found a summarized variation between 1 and $15 \%$ (depending on species) with an average of $4 \%$. The light induced changes of $\mathrm{CC}$ in our study were also modest, with an increase of $6 \%$ for ash and sycamore maple along a light gradient from 3 to $60 \%$ ISF.

Poorter et al. (2006) found that lower CC in low-light leaves results from lower content of total non-structural carbohydrates, lignin and soluble phenolics in low-light leaves. Niinemets (1999) stated that the positive correlation between the concentration of carbon-rich lignin and light is the major reason for the light-dependence of CC. Our results can be interpreted as confirming this statement since the lower construction costs in shade in two of our three species were accompanied by lower carbon content and higher total mineral concentration. Because of these opposed correlations of construction costs with carbon content on one side and with total mineral content on the other side, the ratio between total mineral content and carbon concentration can be seen as a factor which stabilizes foliar construction costs and leads to the above mentioned merely modest variability with light.

The construction costs per unit leaf area $\left(\mathrm{CC}_{\mathrm{A}}\right)$ rose significantly with increasing irradiance in our three species (Fig. 1B). This is in agreement with the results of Barthod and Epron (2005). As low irradiance significantly prolongs the "payback time" of a given investment into leaf construction (i.e. the time necessary to photosynthate carbohydrates in an amount that balances the investment into leaves, Poorter et al., 2006), the reduction of leaf construction costs per unit area certainly has high importance to maintain a positive carbon balance under limiting light conditions. The light dependence of $\mathrm{CC}_{\mathrm{A}}$ was closely paralleled by a highly significant rise of LMA with increasing light in our study in all three species (Tab. I), an observation which has been well documented in many species (Barthod and Epron, 2005; Ellsworth and Reich, 1993; Le Roux et al., 2001; Niinemets, 1997). Poorter et al. (2006) found the higher SLA values of shade leaves being the main factor that constrained the payback time and by this improved the acclimation to shade.

The foliar nitrogen per unit leaf area $\left(N_{\mathrm{a}}\right)$ increase with light (Ellsworth and Reich, 1993; Kull and Niinemets, 1993; Niinemets, 1995; Rosati et al., 1999) and is considered a direct consequence of variation of LMA (Niinemets, 1997). With our data we can confirm this conclusion: Since leaf nitrogen mass content was relatively constant along the light gradient (Tab. I), and since a strong correlation could be observed between LMA and $N_{\mathrm{a}}$, we can conclude that the variability of LMA with irradiance was primarily responsible for the light dependent variation of $N_{\mathrm{a}}$ (Fig. 1D) and presumably for the photosynthetic performance per unit leaf area (cf. Frak et al., 2001; Rosati et al., 1999).

The intra-crown variability of all measured leaf traits followed in principle the same pattern as with light variability above the crowns. From bottom to top crown CC tended to increase weakly, $\mathrm{CC}_{\mathrm{A}}$ and $N_{\mathrm{a}}$ rose considerably (beech by $58 \%$, sycamore maple $66 \%$, ash $87 \%$ ), whereas $N_{\mathrm{m}}$ was independent of crown position (Fig. 3). Only few studies on intra-crown 

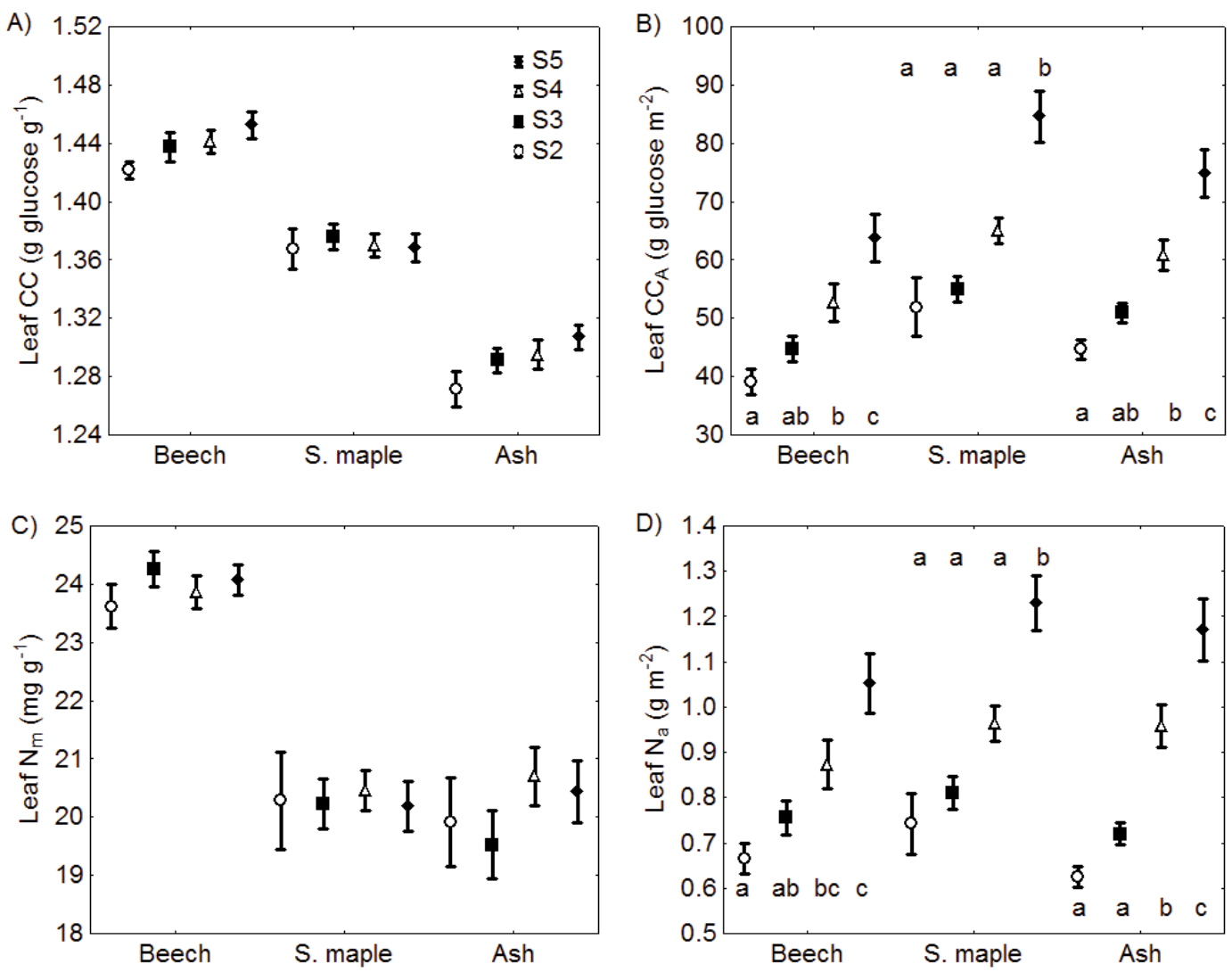

Figure 3. Vertical distribution of (A) leaf specific construction costs $(\mathrm{CC}),(\mathrm{B})$ leaf construction cost per unit leaf area $\left(\mathrm{CC}_{\mathrm{a}}\right)$, $(\mathrm{C})$ leaf nitrogen per unit mass $\left(N_{\mathrm{m}}\right)$, and (D) leaf nitrogen per unit area $\left(N_{\mathrm{a}}\right)$. Box-plots represent mean values and \pm standard errors for four vertical crown layers of equal widths. S2 is the lowest and S5 the topmost layer. The bottommost layer S1 was excluded from the analysis because many plants had no leaves there. Differences between layer mean values were tested with Wilcoxon-pair test. Significant differences are denoted by different letters $(p<0.05)$.

leaf variability have been published and most of them refer to the variation of $N_{\mathrm{m}}, N_{\mathrm{a}}$, LMA and photosynthetic performance (Ellsworth and Reich, 1993; Le Roux et al., 2001). They all concur in showing the same trends within crowns as with irradiance above the crowns.

Unfortunately we were not able to measure light directly within the different crown layers. Therefore we tried to estimate it by using SLA as an indicator for irradiance. SLA has been computed for every crown layer, and the close and highly significant regression between SLA and ISF (measured directly above the crown) $\left(R^{2}>0.74, p<0.01\right)$ allowed us to derive ISF for every crown layer from SLA (for details see Petritan et al., 2009). For our mean sample saplings the results show that in sycamore maple and particularly in ash ISF sharply decreased from $25 \%$ ISF above the crowns to $17 \%$ (sycamore maple) and 10\% (ash) in the second crown layer from above, whereas in beech the respective decline to $23 \%$ ISF in the second crown layer was far less pronounced. In the three following layers the differences between species were less distinct. We assume that the differences at the top of the crowns have been mainly induced by different patterns of leaf area allocation which led to different degrees of self shading: sycamore maple and ash concentrated 85 and $84 \%$ of their to- tal leaf area in the top two layers, beech in contrast located there only $52 \%$. This resulted in less self shading and better illumination which is conveyed by a slightly higher mean ISF of the total leaf area in beech with $18.0 \%$, compared to $17.6 \%$ in sycamore maple and $16.2 \%$ in ash.

Regarding the relationship between leaf traits and shade tolerance, most studies are concerned with LMA (or its invers SLA). Although the relationship between LMA and shade tolerance is not consistent, many studies report that shadeintolerant species tend to have higher LMA than shadetolerant ones when growing under similar light environments (Abrams and Kubiscke, 1990; Barthod and Epron, 2005; Hallik et al., 2009; Niinemets and Kull, 1998). This trend is also supported by our study, as the mid tolerant species ash and sycamore maple exhibited higher LMA values compared with beech.

The generally described tendency of shade intolerant species having higher nitrogen content and photosynthetic capacity per unit leaf area (Gardiner et al., 2009; Hallik et al., 2009; Niinemets, 1997) is also confirmed by our study. Niinemets (1997) assumed that under common irradiance lower $N_{\mathrm{a}}$ in shade tolerant species "allows construction of a larger foliar surface area with the same investment of plant 
nitrogen in leaf production", what should lead to a considerable enhancement of light interception per plant through a more extensive leaf display. In this regard we found in our above mentioned study (Petritan et al., 2009) with saplings of equal heights that along the whole light gradient beech had a significantly greater foliar surface area than ash and sycamore maple. The greater concentration of the foliar area at the top layers of the crown in sycamore maple and ash corresponded to a more pronounced decrease of $N_{\mathrm{a}}$ than in beech (Fig. 3D). Because of the strong correlation between $N_{\mathrm{a}}$ and photosynthetic capacity per unit area (Frak et al., 2001; Le Roux et al., 2001) this possibly optimizes the photosynthetic capacity of the whole crown.

The relationship between species shade tolerance and leaf construction costs has been rarely investigated. Niinemets (1999) found in a study with five deciduous species the leaves of shade tolerant species more expensive to construct compared to leaves of shade intolerant species. He explained this by higher lignin and consequently higher carbon concentrations in the foliage of shade tolerant species at common irradiance. In our study, the shade tolerant beech also exhibited higher carbon concentration and 5 or $10 \%$ higher leaf construction costs compared to sycamore maple and ash, respectively (Tab. I). Similarly, Niinemets (1999) found beech leaves $15 \%$ more expensive than ash leaves, and Barthod and Epron (2005) also observed $8 \%$ higher leaf construction cost in another shade tolerant species Acer platanoides in comparison with ash.

However, energy requirement to built a unit leaf area was lower in our shade tolerant species beech than in sycamore maple and ash, what is consistent with the above described tendency of a lower biomass requirement for the construction of a unit foliar area (i.e. lower LMA) in shade tolerant species (Abrams and Kubiske, 1990; Barthod and Epron, 2005). Thereby shade tolerant species are better adapted to achieve a positive carbon balance under limiting light conditions.

In agreement with previous studies (Niinemets, 1999; Poorter and Bergkotte, 1992; Poorter et al., 2006) we found a negative correlation between total mineral (TM) and carbon concentration (C) (Fig. 2). Total mineral concentration varied from 3 to $8 \%$, with a significant difference between species. The shade tolerant beech had the lowest value $(3 \%)$, indicating that the dilution of leaf organic components by minerals plays a less significant role in changing leaf construction costs compared to less shade tolerant sycamore maple (5\%) and ash (6\%) (Tab. I).

On the basis of the above quoted literature and our own results, the following summarized characteristic of the shade tolerant beech in comparison with the less shade tolerant sycamore maple and ash can be derived:

- Beech possessed higher CC than sycamore maple and ash under all light conditions. CC remained constant with increasing irradiance, whereas it rose weakly in sycamore maple and ash. The extra costs of beech in shade (i.e. $10 \%$ ISF) amounted to ca. $7 \%$ compared to sycamore maple and ca. $13 \%$ compared to ash, in high light (i.e. $50 \%$ ISF) to ca.
$3 \%$ and ca. $9 \%$, respectively. The reason lies in higher values of $\mathrm{C}$ and $N_{\mathrm{m}}$ in beech.

- Beech could compensate this disadvantage by lower LMA values. In shade, they amounted to $21 \%$ respectively $24 \%$ less than in sycamore maple and ash, in high light the difference in favour of beech was even greater (32, respectively $30 \%$ less).

- This resulted in lower $\mathrm{CC}_{\mathrm{A}}$ values in beech. In shade they reached $82-84 \%$ of the respective sycamore maple and ash values, and in high light mere $72-76 \%$. In other words: Out of $1 \mathrm{~g}$ glucose beech could build $237 \mathrm{~cm}^{2}$ leaf area in shade, but sycamore maple and ash only ca. $197 \mathrm{~cm}^{2}$, in high light beech $160 \mathrm{~cm}^{2}$, sycamore maple and ash $118 \mathrm{~cm}^{2}$.

- But this advantage of beech was connected with lower $N_{\mathrm{a}}$ values. Without great differences between shade and high light they amounted only to ca. $86-87 \%$ of the corresponding values of sycamore maple and $83-85 \%$ of ash. From this a lower photosynthetic performance per unit of leaf area can be assumed for beech, both in shade and high light.

- In a companion study (Petriţan et al., 2009) we found that beech could counterbalance this disadvantage by a higher total leaf area per plant. Comparing saplings of equal heights, beech had a total leaf area about twice as high as sycamore maple and ash, independent of irradiance. This also led to a ca. $15 \%$ higher leaf area index in beech $\left(1.46 \mathrm{~cm}^{2} \mathrm{~cm}^{-2}\right)$ as compared to sycamore maple and ash $\left(1.24 \mathrm{~cm}^{2} \mathrm{~cm}^{-2}\right)$. In addition, beech could display this greater leaf area in a way that self shading more constrained than in sycamore maple and ash. As a result, beech leaves on average received more light than leaves of the other two species.

Acknowledgements: We thank Ulrike Westphal, Michael Unger and Martina Knaust from the Institute for Silviculture for their help with collecting the field data and performing the lab work. We are grateful for constructive comments and suggestions of two anonymous reviewers and the editor Dr. Erwin Dreyer, which were really helpful to improve the manuscript.

\section{REFERENCES}

Abrams M.D. and Kubiske M.E., 1990. Leaf structural characteristic of 31 hardwood and conifer tree species in Central Wisconsin: influence of light regime and shade tolerance rank. For. Ecol. Manage. 31: 245253.

Barthod S. and Epron D., 2005. Variations of construction costs associated to leaf area renewal in saplings of two co-occurring temperate tree species (Acer platanoides L. and Fraxinus excelsior L.) along a light gradient. Ann. For. Sci. 62: 545-551.

Ellsworth D.S. and Reich P.B., 1993. Canopy structure and vertical patterns of photosynthesis and related leaf traits in a deciduous forest. Oecologia 96: 169-178.

Frak E., Le Roux X., Millard P., Dreyer E., Jaouen G., Saint-Joanis B. and Wendler R., 2001. Changes in total leaf nitrogen and partitioning of leaf nitrogen drive photosynthetic acclimation to light in fully developed walnut leaves. Plant, Cell Environ. 24: 1279-1288.

Gardiner E.S, Löf M., O’Brien J.J., Stanturf J.A., Madsen P., 2009. Photosynthetic characteristics of Fagus sylvatica and Quercus robur 
established for stand conversion from Picea abies. For. Ecol. Manage. 258: 868-878.

Givnish T.J., 1988. Adaptation to sun and shade: a whole-plant perspective. Aust. J. Plant Phys. 15: 63-92.

Hallik L., Niinemets Ü. and Wright I.J., 2009. Are species shade and drought tolerance reflected in leaf-level structural and functional differentiation in Northern Hemisphere temperate woody flora? New Phytol. 184: 257-274.

Kimmins, J.P., 1997. Forest ecology - a foundation for sustainable management. Prentice Hall, Upper Saddle River/New Jersey, 596 p.

Kitajima K., 1994. Relative importance of photosynthetic traits and allocation patterns as correlates of seedling shade tolerance of 13 tropical trees. Oecologia 98: 419-428.

Kobe, R.K., Pacala, S.W., Silander, J.A., Jr. and Canham, C.D., 1995. Juvenile tree survivorship as a component of shade tolerance. Ecol. Appl. 5: 517-532.

Kull O. and Niinemets Ü., 1993. Variation in leaf. morphometry and nitrogen concentration in Betula pendula Roth., Corylus avellana $\mathrm{L}$. and Lonicera xylosteum L. Tree Physiol. 12: 311-318.

Le Roux X., Walcroft A.S., Daudet F.A., Sinoquet H., Chaves M.M., Rodriques A. and Osorio, L., 2001. Photosynthetic light acclimation in peach leaves: importance of changes in mass: area ratio, nitrogen concentration, and leaf nitrogen partitioning. Tree Physiol. 21: $377-$ 386.

LI-COR, Inc., 1987. Li-3100 Area Meter. Instruction Manual, Lincoln, Nebraska.

Niinemets Ü., 1995. Distribution of foliar carbon and nitrogen across the canopy of Fagus sylvatica: adaptation to a vertical light gradient. Acta Oecol. 16: 525-541.

Niinemets Ü., 1997. Role of foliar nitrogen in light harvesting and shade tolerance of four temperate deciduous woody species. Funct. Ecol. 11: $518-531$.

Niinemets Ü., 1999. Energy requirement for foliage formation is not constant along canopy light gradients in temperate deciduous trees. New Phytol. 144: 459-470.

Niinemets Ü. and Kull O., 1998. Stoichiometry of foliar carbon constituents varies along light gradients in temperate woody canopies: implications for foliage morphological plasticity. Tree Physiol. 18: 467-479.

Niinemets Ü. and Tenhunen J.D., 1997. A model separating leaf structural and physiological effects on carbon gain along light gradients for the shade-tolerant species Acer saccharum. Plant Cell Environ. 20: $845-866$.
Petritan A.M., Lüpke B.v., and Petritan I.C., 2007. Effects of shade on growth and mortality of sycamore maple (Acer pseudoplatanus), ash (Fraxinus excelsior) and beech (Fagus sylvatica) saplings. Forestry 80: $397-412$.

Petritan A.M., Lüpke B.v., and Petritan I.C., 2009. Influence of light availability on growth, leaf morphology and plant architecture of beech (Fagus sylvatica L.), sycamore maple (Acer pseudoplatanus L.) and ash (Fraxinus excelsior L.). Eur. J. For. Res. 128: 61-74.

Poorter H. and Bergkotte M., 1992. Chemical composition of 24 wild species differing in relative growth rate. Plant Cell Environ. 15: 221229.

Poorter H. and Villar R., 1997. The fate of acquired carbon in plants: chemical composition and costruction costs. In: Bazzaz F.A. and Grac J., (Eds.), Plant resource allocation, Academic Press, New York, pp. 39-72.

Poorter H., Pepin S., Rijkers T., DeJong Y., Evans J.R. and Körner C., 2006. Construction costs, chemical composition and payback time of high- and low-irradiance leaves. J. Exp. Bot. 57: 355-371.

Regents Instruments Inc. Sainte-Foy, Québec, 2003. WinScanopy for hemispherical image analysis. www.regent-instruments.com.

Röhrig E, Bartsch N, Lüpke B.v., 2006. Waldbau auf ökologischer Grundlage. Eugen Ulmer (zugleich UTB 8310), Stuttgart, 480 p.

Rosati A., Esparza G., DeJong T.M. and Pearcy R.W., 1999. Influence of canopy light environment and nitrogen availability on leaf photosynthetic nitrogen-use efficiency of field-grown nectarine trees. Tree Physiol. 19: 173-180.

Sims D.A. and Pearcy R.W., 1994. Scaling sun and shade photosynthetic acclimation of Alocasia macrorrhiza to whole-plant performance - I. Carbon balance and allocation at different daily photon flux densities. Plant Cell Environ. 17: 881-887.

StatSoft, Inc. 2005 STATISTICA für Windows [Software-System für Datenanalyse] Version 7.1. http://www.statsoft.com.

Valladares F. and Niinemets Ü., 2008. Shade Tolerance, a Key Plant Feature of Complex Nature and Consequences Annu. Rev. Ecol. Evol. Syst. 39: 237-57.

Vertregt N. and Penning de Vries F.W.T., 1987. A rapid method for determining the efficiency of biosynthesis of plant biomass. J. Theor. Biol. 128: 109-119.

Wright I.J., Reich P.B., Westoby M., Ackerly D.D., Baruch Z., Bongers F., Cavender-Bares J., Chapin T., Cornelissen J.H.C. et al., 2004. The world-wide leaf economics spectrum. Nature 428: 821-827. 